\title{
The Nearby Doctor Search Application Based on Android
}

\author{
Steven Wisnu Cahya Putra, Albertus Dwi Yoga Widiantoro, Bernardinus Harnadi \\ Department of Information System, Faculty of Computer Science, \\ Soegijapranata Catholic University, Semarang, Indonesia \\ stevenwisnucp@gmail.com,yoga@unika.ac.id,b_harnadi@yahoo.com
}

\begin{abstract}
This study aims to design the nearest doctor search application based on Android. The application is designed to find the nearest doctor and emergency room, show a list of emergency rooms and general doctor and specialists who open practice in Semarang area, and order queues online. The design of this application uses survey results to get data about application requirements. The application is designed based on the needs of the people who use the services of a private practice doctor and is expected to help the community in ordering queues to see a private practice doctor. The application was tested to 45 respondents ages 16-35 years who had tried the application 2-4 times. The test results state that application users will continue to be willing to use it if the application is easy to use and they have the device to run the application.
\end{abstract}

Keyword- Application, Personal Practice Doctor, Android, Queue.

\section{INTRODUCTION}

Today's public health is a very important thing to consider. Some people choose to go to a private doctor for treatment. But some people do not know the location of the nearest private practice doctor and emergency room, and people often experience long queue problems because they still have to register manually.

The queue process is a process that related to the arrival of patients in a service facility. Then the patient waits in the queue line if it cannot be served, and leaves the service facility when it has been served [1].

While the doctor's search process is a process that related to the presence of the doctor to be directed by the patient to order the queue.
The development of internet technology has become one of the effective solutions for manage patient medical record data with private practice doctors. Patient medical records can be stored digitally so that data can be accessed on a mobile basis [2].

So, Doctor Nearby application media is designed to make it easier for people to find the location of the practice of the nearest general doctor and specialist and emergency room. Even this application can help people order queues online.

A indication of a illness is the beginning of a illness that can intimidate a person's health, but in fact the indication of the illness are sometimes underestimated by most people [3].

In the application term, the application is a pre-designed program designed to perform a function for other users or applications and may be used by the intended target [4].

Global Positioning System or called GPS is a system to determine the location of the earth's surface with the help of synchronization of satellite signals. You can browse locations when a user changes location, you can determine the location of the phone then access the web to determine the public location that is close to the user [5].

Android is an operating system for mobile devices that is currently developing. Application development for Android information systems is divided into three, are native application development (Java), web application development (PHP) and hybrid application development (Java + PHP) [4].

Apache Cordova is a free open source framework for building cross-platform. The original application using HTML5 Cordova consists of a collection of API devices that allow developers to access native functions of 
a device and create applications on various platforms such as Android, Blackberry, Iphone or Windows Phone [6].

Database is a collection of logical relations from data or data descriptions that can be used together and made to obtain information needed by the company. The database consists of entities, attributes and relationships of organizational or company information [7].

\section{METHOD}

\section{A. Application Development Methods}

The development of the Doctor Nearby application starts with defining the concept in the Doctor Nearby application flow and following the application development flowchart.

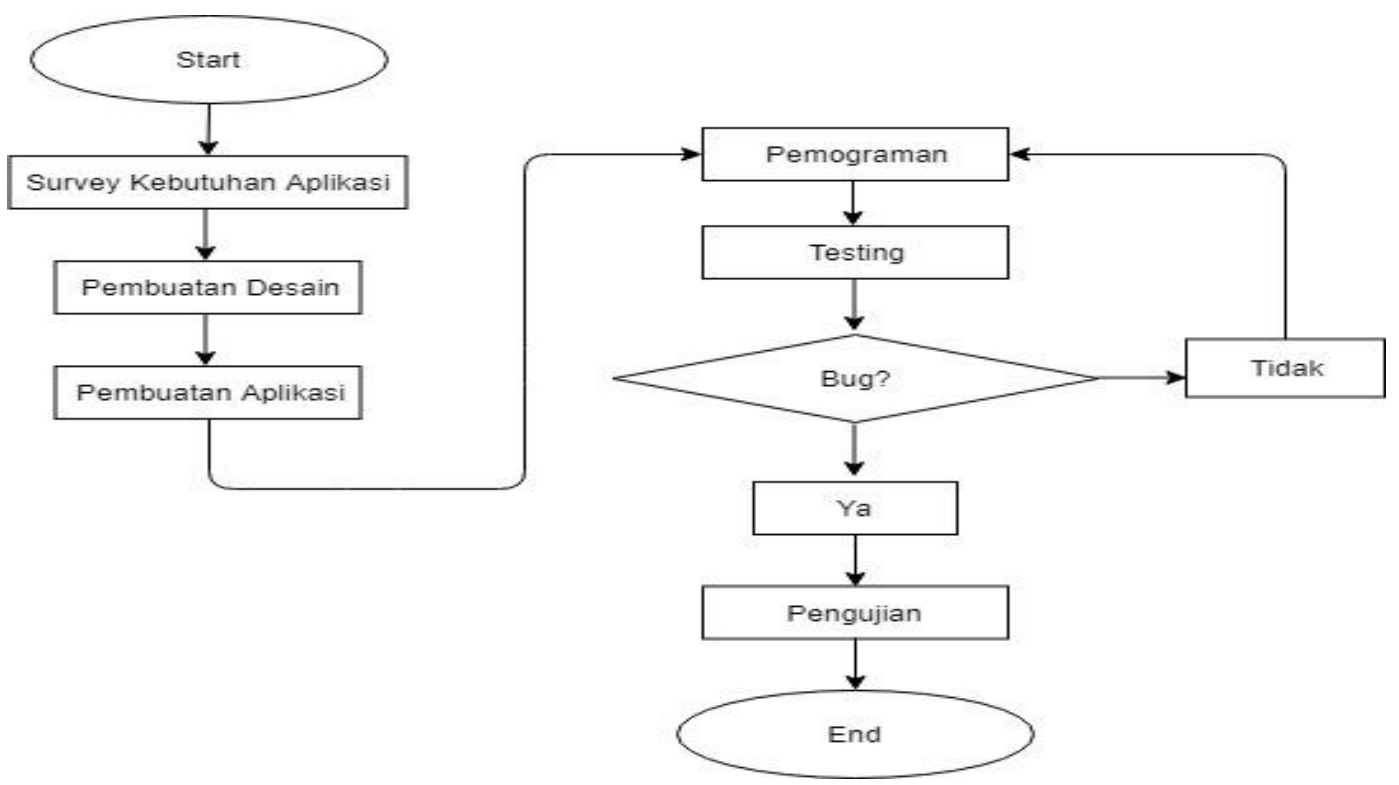

Figure 1. Application Development Flowchart

Then continued with the process of make a design use Adobe Photoshop. The next process is making an application use the Apache Cordova program. After the application is completed, then it is continued by a testing process to maximize the application and minimize bugs.

\section{B. Data Collection Techniques}

The technique used in this data collection is by survey and give questionnaires to the general public in Semarang area.

\section{Data Sources}

Primary data sources were obtained directly from respondents. In this study the primary data source is the questionnaire results from respondents before and after use the application. Secondary data sources that the data obtained is concrete data originating from existing journals that explain the convenience for android users to find the nearest private practice doctor and emergency room.

\section{RESULT AND DISCUSSION} A. Survey results for Application Needs

Before starting the application, a study to get data what people needs about the Doctor Nearby application can help people to find the nearest doctor. The study was conducted by distributing questionnaires to 40 people with an average age of 16-35 years. There are nine questions answered by respondents and the results are shown in Table 1. 
Table 1. Frequency of Respondent Answers

The results Table 1 shows that people needs a Doctor Nearby application.

\begin{tabular}{|c|c|c|c|c|c|}
\hline No & Pertanyaan & \multicolumn{4}{|c|}{ Jawaban Responden } \\
\hline 1 & $\begin{array}{l}\text { Jika anda sakit, kemana kah } \\
\text { anda pergi untuk berobat }\end{array}$ & $\begin{array}{l}51 \% \text { pergi } \\
\text { rumah sakit }\end{array}$ & \multicolumn{2}{|c|}{$\begin{array}{l}29 \% \text { pergi ke dokter } \\
\text { praktek pribadi }\end{array}$} & $\begin{array}{l}20 \% \text { pergi } \\
\text { puskesmas }\end{array}$ \\
\hline 2 & $\begin{array}{l}\text { Bagaimana cara anda dalam } \\
\text { menemukan dokter yang } \\
\text { membuka praktek pribadi }\end{array}$ & $\begin{array}{l}64 \% \text { berdasarkan } \\
\text { dokter terdekat }\end{array}$ & \multicolumn{2}{|c|}{$\begin{array}{l}20 \% \text { berdasarkan } \\
\text { rekomendasi dari } \\
\text { teman }\end{array}$} & $\begin{array}{l}16 \% \\
\text { informasi } \\
\text { internet }\end{array}$ \\
\hline 3 & $\begin{array}{l}\text { Seberapa sering anda } \\
\text { mengunjungi dokter }\end{array}$ & $\begin{array}{l}78 \% \text { sebanyak } 1-2 \\
\text { kali dalam kurun } \\
\text { waktu satu bulan }\end{array}$ & \multicolumn{2}{|c|}{$\begin{array}{l}20 \% \text { sebanyak } 3-4 \text { kali } \\
\text { dalam kurun waktu } \\
\text { satu bulan }\end{array}$} & $\begin{array}{l}2 \% \text { sebanyak } 5 \text { kali } \\
\text { atau lebih } \begin{array}{r}\text { dalam } \\
\text { kurun waktu satu } \\
\text { bulan }\end{array}\end{array}$ \\
\hline 4 & \begin{tabular}{lcr} 
Apakah & anda & \multicolumn{2}{c}{ sebelumnya } \\
pernah & menggunakan & aplikasi \\
untuk & menemukan & dokter \\
pribadi & &
\end{tabular} & $\begin{array}{l}56 \% \text { tidak } \\
\text { mengetahui sama } \\
\text { sekali aplikasi } \\
\text { untuk menemukan } \\
\text { dokter pribadi } \\
\text { sebelumnya }\end{array}$ & \multicolumn{2}{|c|}{$\begin{array}{l}42 \% \text { tidak pernah } \\
\text { menggunakan aplikasi } \\
\text { untuk menemukan } \\
\text { dokter r pribadi } \\
\text { sebelumnya }\end{array}$} & $\begin{array}{lr}2 \% & \text { responden } \\
\text { pernah menggunakan } \\
\text { aplikasi } & \text { untuk } \\
\text { menemukan } & \text { dokter } \\
\text { pribadi } & \end{array}$ \\
\hline 5 & $\begin{array}{l}\text { Jika pernah menggunakan, } \\
\text { apakah menurut anda aplikasi } \\
\text { tersebut telah menyediakan } \\
\text { informasi yang lengkap terkait } \\
\text { dokter praktek pribadi }\end{array}$ & \multicolumn{2}{|c|}{$\begin{array}{l}96 \% \text { menjawab tidak karena } \\
\text { sebagian besar responden belum } \\
\text { pernah atau bahkan tidak tahu } \\
\text { sama sekali tentang aplikasi } \\
\text { untuk menemukan dokter } \\
\text { pribadi }\end{array}$} & \multicolumn{2}{|c|}{$\begin{array}{l}4 \% \text { menjawab aplikasi } \\
\text { sebelumnya telah menyediakan } \\
\text { informasi yang lengkap terkait } \\
\text { dokter praktek pribadi }\end{array}$} \\
\hline 6 & $\begin{array}{l}\text { dokter umum } \\
\text { praktek pribad }\end{array}$ & \multicolumn{2}{|c|}{$\begin{array}{l}78 \% \text { responden yang tidak } \\
\text { mengetahui daftar dokter umum } \\
\text { yang membuka praktek pribadi }\end{array}$} & \multicolumn{2}{|c|}{$\begin{array}{l}\text { 22\% responden yang mengetahui } \\
\text { daftar dokter umum yang } \\
\text { membuka praktek pribadi }\end{array}$} \\
\hline 7 & $\begin{array}{l}\mathrm{h} \text { anda mengetahu } \\
\text { spesialis yang me } \\
\text { k pribadi }\end{array}$ & \multicolumn{2}{|c|}{$\begin{array}{l}78 \% \text { responden yang tidak } \\
\text { mengetahui daftar dokter } \\
\text { spesialis yang membuka praktek } \\
\text { pribadi }\end{array}$} & \multicolumn{2}{|c|}{$\begin{array}{l}22 \% \text { responden yang mengetahui } \\
\text { daftar dokter spesialis yang } \\
\text { membuka praktek pribadi }\end{array}$} \\
\hline 8 & $\begin{array}{l}\text { elalu mengalami } \\
\text { antrian panjang } \\
\text { gunjungi dokter }\end{array}$ & \multicolumn{2}{|c|}{$\begin{array}{l}91 \% \text { responden setuju dengan } \\
\text { masalah antrian panjang pada } \\
\text { saat mengunjungi dokter praktek } \\
\text { pribadi }\end{array}$} & \multicolumn{2}{|c|}{$\begin{array}{l}9 \% \text { responden tidak setuju } \\
\text { dengan masalah antrian panjang } \\
\text { pada saat mengunjungi dokter } \\
\text { praktek pribadi }\end{array}$} \\
\hline 9 & $\begin{array}{l}\text { Informasi tentang UGD seperti } \\
\text { apakah yang anda butuhkan }\end{array}$ & $\begin{array}{l}53 \% \text { responden } \\
\text { memilih informasi } \\
\text { tentang dokter jaga } \\
\text { yang berada di } \\
\text { UGD }\end{array}$ & \multicolumn{2}{|c|}{$\begin{array}{l}45 \% \text { memilih } \\
\text { informasi tentang alat- } \\
\text { alat penunjang hidup } \\
\text { yang berada di UGD }\end{array}$} & $\begin{array}{lr}2 \% & \text { memilih } \\
\text { informasi tentang } \\
\text { ambulan UGD }\end{array}$ \\
\hline
\end{tabular}

\section{B. Doctor Nearby Application}

Doctor Nearby application is the nearest doctor application that is applied in android. This application is made aiming to find the nearest doctor's practice place so that it is easier to find. This application is made use Cordova with an application size of approximately $12.24 \mathrm{MB}$. The Doctor Nearby application can be used on the Android platform.

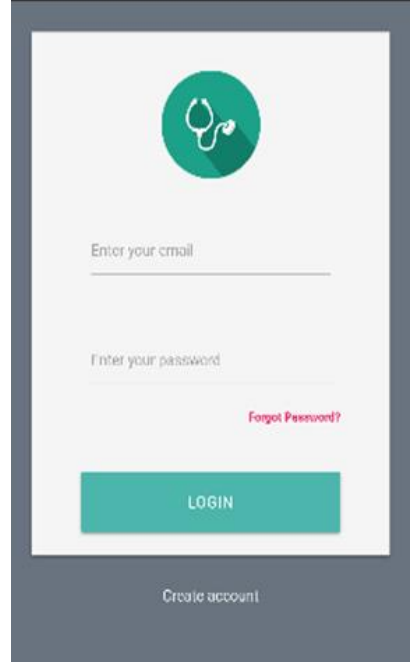

Figure 2. Example of Display Doctor Nearby Application 
While there are several display menu including home menu, doctor menu, emergency room menu, and doctor's added menu.

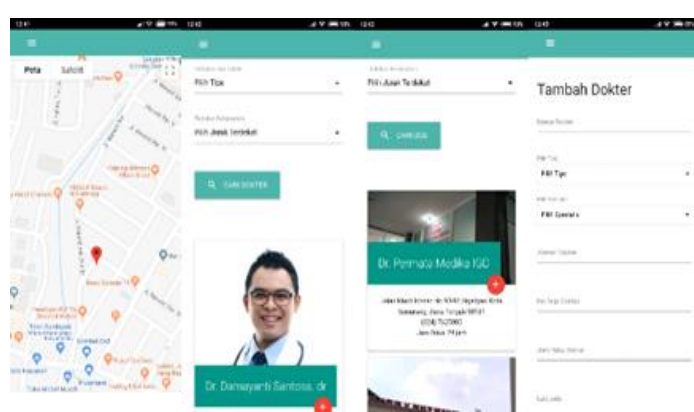

Figure 3.Example of Display Menu Doctor Nearby Application

\section{Application Operations}

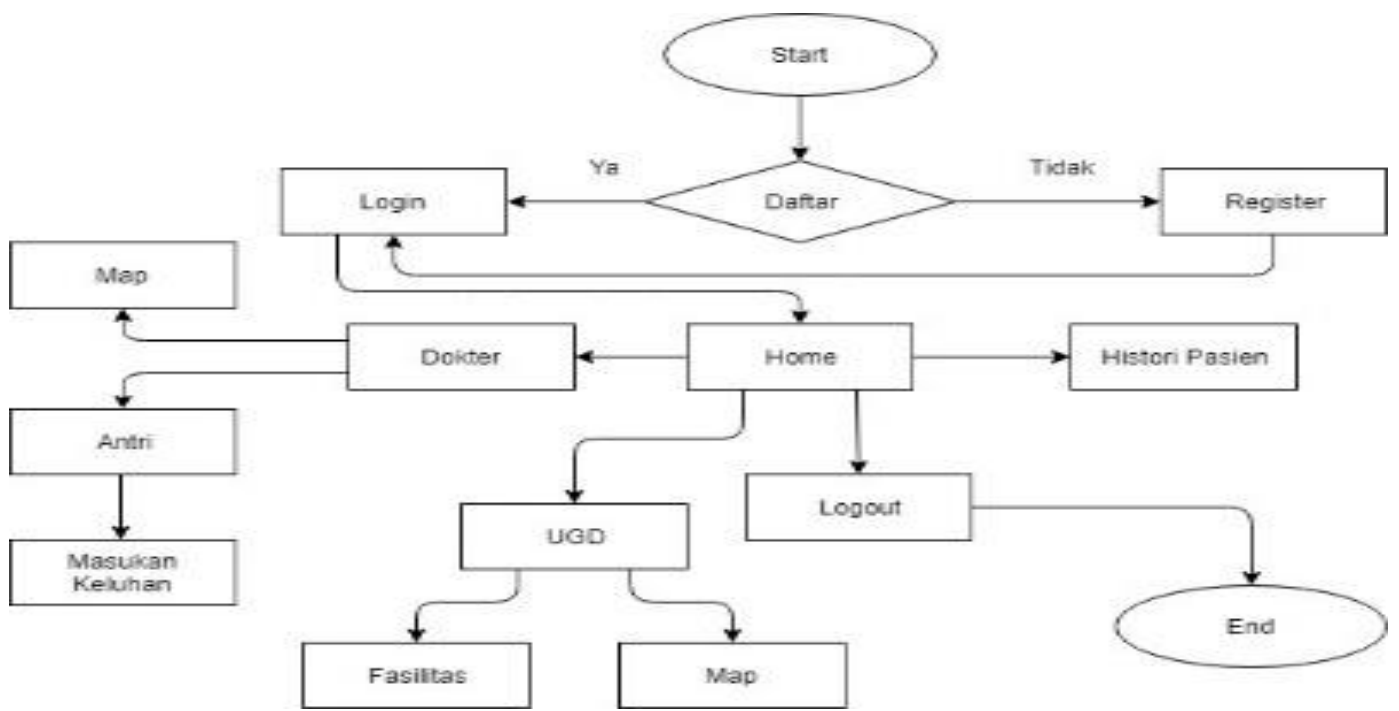

Figure 4.Doctor Nearby Application Operations Flowchart

D. Application Testing

a) Testing Model

Applications are tested use hypotheses:

1. EE variable (convenience) has a strong influence on I variable (intention).

2. PE variable (usability) has a strong influence on I variable (intention).

3. FC variable (availability of facilities) has a strong influence on I variable (intention).

The questionnaire instrument was made based on the hypothesis was submitted and distributed to user candidates. The test questionnaire data collected was 45 and requires testing the validity and reliability of the research variables.

\section{b) Validity of Questionnaire} Variables

The research variables used in the study were: Convenience (EE), Usability (PE), Facility Availability (FC), and Intention (I) to use the Doctor Nearby application. All variables need to be tested for validity to ensure the questions can represent each variable correctly and represent the attitudes of the respondents. To test the validity of each variable, the Principal Component Factor Analysis test is done as shown in Table 2. From Table 2, seems that in PE4, FC2, FC3 variables are invalid after being compared with $r$ table, therefore they are retested by not including the PE4 and FC3 variables. 
Table 2. Validity Test Result

\begin{tabular}{|l|c|c|c|}
\hline & $\begin{array}{c}\text { Corrected Item-Total } \\
\text { Correlation }\end{array}$ & $\begin{array}{c}\mathrm{r} \\
\text { tabel }\end{array}$ & Hasil \\
\hline EE1 & .414 & .294 & valid \\
EE2 & .382 & .294 & valid \\
EE3 & .524 & .294 & valid \\
PE1 & .567 & .294 & valid \\
PE2 & .321 & .294 & valid \\
PE3 & .359 & .294 & valid \\
PE4 & .265 & .294 & Tidak \\
& .512 & .294 & valid \\
FC1 & .262 & .294 & Tidak \\
FC2 & .250 & .294 & valid \\
FC3 & .334 & .294 & valid \\
I1 & .364 & .294 & valid \\
I2 & .474 & .294 & valid \\
\hline I3 & & & valid \\
\hline
\end{tabular}

After the PE4 and FC3 variables are not included, then a test is using the Principal Component Factor Analysis to show the level of convergence of indicators in each variable and the results are shown in Table 3. Table 3 shows that the EE3 indicator is not convergent in EE variable and $\mathrm{I} 3$ is not convergent in I variable, therefore the second test by not including indicators between EE3 and I3.

Table 3. Validity Test Result

\begin{tabular}{|c|c|c|c|c|}
\hline \multirow{2}{*}{} & \multicolumn{4}{|c|}{ Component } \\
\cline { 2 - 5 } & 1 & 2 & 3 & 4 \\
\hline EE1 & .483 & .674 & .038 & -.294 \\
EE2 & .680 & .226 & -.092 & .235 \\
EE3 & .029 & .911 & .146 & .079 \\
PE1 & -.082 & .369 & .794 & .131 \\
PE2 & -.150 & .205 & .784 & -.060 \\
PE3 & .184 & -.108 & .766 & .165 \\
FC1 & .425 & .100 & .138 & .783 \\
FC2 & -.058 & .037 & .055 & .914 \\
I1 & .848 & .133 & -.043 & .037 \\
I2 & .816 & .047 & .069 & .098 \\
I3 & .146 & .719 & .178 & .196 \\
\hline
\end{tabular}

Testing with the Principal Component Factor Analysis is done in stages by not including EE3 indicator. And the results are shown in Table 4. It turns out that from the table I3 indicator have convergence with other indicators in I variable.

Table 4. Validity Test Result

\begin{tabular}{|c|c|c|c|}
\hline \multirow{2}{*}{} & \multicolumn{3}{|c|}{ Component } \\
\cline { 2 - 4 } & 1 & 2 & 3 \\
\hline EE1 & .719 & .258 & -.355 \\
EE2 & .704 & -.073 & .267 \\
PE1 & .014 & .888 & .110 \\
PE2 & -.097 & .841 & -.077 \\
PE3 & .019 & .571 & .310 \\
FC1 & .403 & .136 & .802 \\
FC2 & -.045 & .106 & .865 \\
I1 & .824 & -.075 & .106 \\
I2 & .765 & .022 & .163 \\
I3 & .428 & .471 & .063 \\
\hline
\end{tabular}

Therefore the results of Table 4 are stated valid and the indicators used for the next test are EE1, EE2, PE1, PE2, PE3, FC1, FC2, I1, I2, I3.

\section{c) Reliability of Questionnaire Variables}

Cronbach's Alpha coefficient is used to reliability testing (Level of Trust) on the questionnaire. From the results of the reliability testing in Table $5 \mathrm{EE}$ variable included in the poor category, PE and FC variables included in the Acceptable category, while for I variable included in the Questionable category. This calculation is suitable with the Internal Consistency Cronbach alpha in Table 6.

Table 5. Reliability Result

\begin{tabular}{|l|l|l|}
\hline \multicolumn{1}{|c|}{ Variabel } & \multicolumn{1}{|c|}{$\begin{array}{c}\text { Koefisien } \\
\text { Cronbach's } \\
\text { Alpha }\end{array}$} & \multicolumn{1}{|c|}{ Hasil } \\
\hline Kemudahan (EE) & 0,585 & Poor \\
\hline Kebergunaan (PE) & 0,724 & Acceptable \\
\hline $\begin{array}{l}\text { Ketersediaan } \\
\text { Fasilitas (FC) }\end{array}$ & 0,743 & Acceptable \\
\hline $\begin{array}{l}\text { Intensu } \\
\text { menggunakan (I) }\end{array}$ & 0,674 & Questionable \\
\hline
\end{tabular}

Table 6. Internal Consistency Cronbach alpha

\begin{tabular}{|l|l|}
\hline Cronbach's alpha & \multicolumn{1}{c|}{ Internal consistency } \\
\hline$\alpha \geq 0.9$ & Excellent \\
\hline $0.9>\alpha \geq 0.8$ & Good \\
\hline $0.8>\alpha \geq 0.7$ & Acceptable \\
\hline $0.7>\alpha \geq 0.6$ & Questionable \\
\hline $0.6>\alpha \geq 0.5$ & Poor \\
\hline $0.5>\alpha$ & Unacceptable \\
\hline
\end{tabular}




\section{d) Correlation Test}

From Table 7 seems that Convenience (EE) and Equality of Facilities (FC) variables have a strong correlation with the Intention (I) variable. Exceptions are found in the Usability (PE) variable not having a correlation with the Intention (I) variable. This means that the convenience of use of the application (EE) and Availability of Facilities in using the application (FC) has a very close relationship with the desire of users to continue to use (I) the Doctor Nearby application. Therefore the intention to continue using the Doctor Nearby application is strongly influenced by the convenience of use of the application and the availability of facilities but is not influenced by the usability of the Doctor Nearby application.

Table 7. Correlation Test Result

\begin{tabular}{|c|c|c|c|c|c|c|c|c|c|c|}
\hline & $\bar{A}$ & $\overline{\mathrm{O}}$ & $S$ & FK & $\mathrm{AK}$ & $\mathrm{G}$ & SEE & SPE & SFC & SI \\
\hline $\mathrm{A}$ & 1 & $-.752^{* * *}$ & $.683^{* *}$ & -.066 & $-.304^{*}$ & .225 & -.003 & $-.426^{* *}$ & $.564^{* *}$ & .038 \\
\hline $\mathrm{O}$ & $-.752^{* *}$ & 1 & $-.525^{* * *}$ & -.060 & 220 & $-.374^{*}$ & .079 & $.340^{*}$ & $-.447^{* *}$ & .054 \\
\hline $\bar{S}$ & $.683^{* *}$ & $-.525^{* *}$ & 1 & -.015 & -.197 & .244 & -.127 & $-.313^{*}$ & $.341^{*}$ & -.191 \\
\hline FK & -.066 & -.060 & -.015 & 1 & -.224 & .143 & -.001 & .229 & -.005 & -.077 \\
\hline$\overline{\mathrm{AK}}$ & $-.304^{*}$ & .220 & -.197 & -.224 & 1 & .000 & .174 & .157 & .042 & .180 \\
\hline $\bar{G}$ & .225 & $-.374^{*}$ & .244 & .143 & .000 & 1 & -.174 & -.077 & 201 & $\begin{array}{l}-.011 \\
\end{array}$ \\
\hline SEE & -.003 & .079 & -.127 & -.001 & .174 & -.174 & 1 & .085 & .222 & $.534^{* *}$ \\
\hline SPE & $-.426^{* *}$ & $.340^{*}$ & $-.313^{*}$ & .229 & 157 & -.077 & .085 & 1 & .222 & .120 \\
\hline SFC & $.564^{* * *}$ & $-.447^{* * *}$ & $.341^{*}$ & -.005 & .042 & .201 & .222 & .222 & 1 & $330^{*}$ \\
\hline SI & .038 & .054 & -.191 & -.077 & 180 & -.011 & .534** & .120 & $.330^{*}$ & 1 \\
\hline
\end{tabular}

\section{CONCLUSION}

Doctor Nearby application is an application that can find several private practice doctors where location is nearest to its users. From the results of testing conducted on 45 respondents, it was concluded that the Doctor Nearby Application is easy to use and provides information on several facilities so that users will continue to use the Doctor Nearby application. While the perception of usability has no effect on the intention to use the application.

\section{REFERENCES}

[1] A. S. Septiani, P. A. Wigati, and E. Y. Fatmasari, "Gambaran Sistem Antrian Pasien Dalam Optimasi Pelayanan Di Loket Pendaftaran Instalasi Rawat Jalan Rumah Sakit Umum Pusat Fatmawati," Biomed. Tech., vol. 57, no. SI-1 Track-F, p. 170, 2012.

[2] Yusrizal, R. Dawood, and Roslidar, "Rancang Bangun Layanan Web (Web Service) Untuk Aplikasi Rekam Medis Praktik Pribadi Dokter," KITEKTRO J. Online Tek. Elektro, vol. 2, no. Januari, pp. 1-8, 2017.
[3] A. H. Situmorang, I. N. Hakim, and M. Shofyan, "Aplikasi Sistem Pakar Untuk Mendiagnosa Penyakit Metode Forward Channing," pp. 6-7, 2016.

[4] P. D. I. Raa and Y. Sinatra, "Rancang Bangun Aplikasi Delivery Order Berbasis Android di Ageng Bakery Group Blitar," Sinteks J. Tek., vol. 5, no. 2, 2017.

[5] A. A. A. Makiolor, A. A. E. Sinsuw, and X. B. N. Najoan, "Rancang Bangun Pencarian Rumah Sakit, Puskesmas dan Dokter Praktek Terdekat di Wilayah Manado Berbasis Android," e-journal Tek. Inform. Univ. Sam Ratulangi, vol. 10, no. 1, pp. 1-10, 2017.

[6] N. A. Widiastuti, "Aplikasi mobile pada sentra industri seni patung dan ukir di desa mulyoharjo untuk meningkatkan potensi pasar," vol. 3, pp. 17-24, 2018.

[7] N. K. A. W. Harmandya, Mentari, Gusti Made Arya Sasmita, "Rancang Bangun Aplikasi Tryout Ujian Nasional Sekolah Menengah Pertama (SMP) Berbasis Android," Lontar Komput., vol. 6, no. 2, pp. 108-119, 2015. 